\title{
Grain yield of aerobic rice as influenced by seed rate and row spacing in aer- obic situation under changed climate
}

\author{
K. Jana ${ }^{1}$, S. K. Das ${ }^{1}$, G. Moinuddin ${ }^{1}$, G. K. Mallick² and B. Biswas ${ }^{1}$ \\ ${ }^{1}$ Directorate of Research, Bidhan Chandra Krishi Viswavidyalaya, Nadia, Kalyani- 741235 (West Bengal), INDIA \\ ${ }^{2}$ Rice Research Station, Bankura - 722101 (West Bengal), INDIA \\ *Corresponding author. E-mail: kjanarrs@gmail.com \\ Received: March 23, 2016; Revised received: August 17, 2016; Accepted: November 18, 2016;
}

\begin{abstract}
Aerobic rice system is the method of cultivation, where the rice crop is established by direct seeding in un-puddle field. The grain yield of aerobic rice in aerobic situation realized by the farmers is still lower. Among many factors, seed rate and row spacing influence the grain yield of aerobic rice crop. The present investigation was carried out to study the influence of seed rates and row spacing on grain yield of aerobic rice in aerobic situation, and field experiment was conducted at Rice Research Station, Bankura, West Bengal, India during kharif season of 2011 and 2012. The experimental results exhibited that the highest grain yield $\left(3.40,3.49\right.$ and $3.42 \mathrm{t} \mathrm{ha}^{-1}$ during kharif 2011, kharif 2012 and in pooled value, respectively) was recorded from treatment $\mathrm{S}_{2}$, where seed rate was $30 \mathrm{~kg}$ ha 1 . Among the different row spacing, the maximum grain yield of $3.47,3.45$ and $3.46 \mathrm{t} \mathrm{ha}^{-1}$ during kharif season of 2011 and 2012 and on pooled basis was obtained with the treatment $R_{1}$ i.e. $20 \mathrm{~cm}$ row spacing. The treatment combination of $S_{2}$ (seed rate @ $\left.30 \mathrm{~kg} \mathrm{ha}^{-1}\right)$ and $\mathrm{R}_{1}\left(20 \mathrm{~cm}\right.$ row spacing) recorded the highest grain yield $\left(4.01 \mathrm{t} \mathrm{ha}^{-1}\right)$ of aerobic rice. It was established that the seed rate @ $30 \mathrm{~kg} \mathrm{ha}^{-1}$ and $20 \mathrm{~cm}$ row spacing was promising for realizing best grain yield of aerobic rice in aerobic condition. It is an important eco-safety tool for tackling the climate change scenario.
\end{abstract}

Keywords: Aerobic rice, Changed climate, Food security, Row spacing, Seed rate

\section{INTRODUCTION}

Rice (Oryza sativa L.) is an important cereal crop and grown across the world. It is a staple food of more than $60 \%$ of World's population and provides more calories per hectare than any other crop (Faisul-ur-Rasool et al., 2013). By the end of $21^{\text {st }}$ Century, the earth's climate is predicted to warm by an average of $2-4^{0} \mathrm{C}$ (IPCC, 2007) due to anthropogenic and natural factors (Eitzinger et al., 2010). Rice cultivation is a water intensive enterprise. However, lowland rice fields have relatively high water requirements and their sustainability is threatened by increasing water shortages (Bouman and Tuong, 2001). Rice consumes more than $50 \%$ of the water used for irrigation in Asia (Barker et al., 1999). Aerobic rice system is the method of cultivation, where the rice crop is established by direct seeding (dry or water-soaked seed) in un-puddle field and non-flooded field condition (Jana, 2012a). The usual way of planting aerobic rice is the same as we would plant the other cereal crops like wheat, oats or maize by direct seeding. There is no need of raising of seedling in nursery bed and puddle operation in the main field (Jana, 2012b). Compared with flooded lowland rice, aerobic rice requires $30-50 \%$ less water (Bouman et al., 2005). Supplementary irrigation is applied in aerobic rice system of cultivation as and when required and can be supplied in the same way as to any upland cereals crops like maize, wheat (Bouman et al., 2005; Wang et al., 2002). Aerobic rice system in un-puddled situation during boro season by using short duration rice varieties is possible through good agronomic management practices and it is the rice for future (Jana, 2013). Hence, shifting gradually from traditional rice production system to growing rice in aerobic condition especially in upland and mid-upland situation during kharif season can mitigate the problem. The grain yield levels realized by the farmers under upland situations are still lower. Among many factors, method of sowing, seed rate (Kathiresan and Manoharan, 2002) influence the crop yield level greatly under upland situations. Like fertilizers, seed is also costly input. The quantity of seed is therefore required to be used judiciously particularly in view of the fact that the farmers in rainfed areas are generally poor. Special attention should be given for increasing the yield per unit area by applying improved technology and management practices (Mankotia et al., 2005). Among the cultural technologies, planting density is one of the important components, manipulation of which is an essence for optimizing yield (Faisul-ur-Rasool et al., 2013). Information of optimum seed rates with varying levels of row spacing for maximizing grain yield of aerobic rice under aerobic situation are scanty (Jana, 
2013) and sufficient information regarding their optimum planting density under different agro-climatic condition of West Bengal have not been generated so far. Therefore, an attempt was made for achieving maximum production of grain yield of aerobic rice in aerobic situation during kharif season under changed climate. Therefore, present investigation was carried out with a view to develop a package involving optimization of seed rate i.e. seed requirement and proper row spacing for the overall improvement of productivity of rainfed upland aerobic rice.

\section{MATERIALS AND METHODS}

The research-based information on the seed rate and row spacing of aerobic rice system is very meagre. So, on the basis of this fact, a field experiment on 'Grain yield of aerobic rice as influenced by seed rate and row spacing in aerobic situation under changed climate' was conducted during kharif season of 2011 and 2012 at Rice Research Station, Bankura, West Bengal, India on sandy loam soil. This experiment was laid out in split plot design in three replications with three levels of seed rates $\left(\mathrm{S}_{1}-25, \mathrm{~S}_{2}-30\right.$ and $\left.\mathrm{S}_{3}-35 \mathrm{~kg} \mathrm{ha}^{-1}\right)$ randomly allotted in the three main plots; while three different row spacing (row to row distance: $R_{1}-20, R_{2}$ 25 and $R_{3}-30 \mathrm{~cm}$ ) were randomly allotted in the three sub plots of each main plot. The plot size was $5 \mathrm{~m} \mathrm{X}$ $4 \mathrm{~m}$. The rice variety was Kshitish (IET 4094). The date of direct sowing in un-puddled field was 15.07.2011 and 10.07.2012, respectively. Direct seeding of dry seed treated with carbendazim @ 2g per kg seed was done. The required cultural practices and plant protection measures were followed as per recommended package.

Fertilizer management: The recommended dose was $\mathrm{N}, \mathrm{P}_{2} \mathrm{O}_{5}, \mathrm{~K}_{2} \mathrm{O} @ 80,40,40 \mathrm{~kg} \mathrm{ha}{ }^{-1} .25 \%$ of recommended dose of nitrogen, full dose of phosphorus, 75\% of potash and $\mathrm{ZnSO}_{4} @ 25 \mathrm{~kg} \mathrm{ha}^{-1}$ was applied as basal. Remaining dose of $\mathrm{N}$ in two splits was applied. $50 \% \mathrm{~N}$ at active tillering stage and $25 \% \mathrm{~N}$ along with $25 \%$ Potash at panicle initiation stage were applied.

Weed management: Pendimethalin (PE) @ $1.0 \mathrm{~kg}$ a.i. $\mathrm{ha}^{-1}$ at 1 day after sowing (DAS) and 2, 4-D Na salt (80 WP)@0.8 kg a.i. ha ${ }^{-1}$ at 20 DAS was applied. One hand weeding was done at 55 DAS.

Characteristics of soil: The characteristics of red and laterite soils are poor in organic matter content, available phosphate and in bases. The upland soils are mostly eroded with a very low water holding capacity. Crust formation in the upland soils is serious problem. This experiment was conducted in upland. The texture of experimental soil was sandy loam with slightly acidic in nature (pH: 5.6), $0.15 \mathrm{ds} \mathrm{m}^{-1} \mathrm{EC}$, organic carbon $0.48 \%$, available $\mathrm{P}_{2} \mathrm{O}_{5} 52 \mathrm{~kg} \mathrm{ha}^{-1}$ and available $\mathrm{K}_{2} \mathrm{O}$ $166 \mathrm{~kg} \mathrm{ha}^{-1}$.

Observation on yield parameters and yield was recorded. Data was statistically analysed. The $5 \mathrm{~m}^{2}$ area in the middle of each plot was harvested for recording grain yield. Ten rice hills outside the harvested area were selected and harvested separately for recording panicle weight. The number of matured panicles per $\mathrm{m}^{2}$ area in the middle of each plot was recorded. Harvesting was done on 03.11.2011 and 28.10.2012, respectively.

\section{RESULTS AND DISCUSSION}

Seed rate and row spacing as well as planting density are one of the most important factors that determine the grain yields of aerobic rice. The growth, development and grain yield of rice are greatly influenced by the row spacing under field conditions as reported by Jalil, 2008. There was a remarkable difference in respect of yield and yield contributing characters of aerobic rice due to seed rate and row spacing.

Matured panicles: The experimental results revealed that the treatment $S_{2}$ i.e. seed rate@30 kg ha ${ }^{-1}$ significantly recorded more number of matured panicles $\mathrm{m}^{-2}$ (367) in pooled value. Lowest number of matured panicles $\mathrm{m}^{-2}$ (331 as pooled value) was obtained with the seed rate@25 kg ha ${ }^{-1}$ and it was statistically at par with the seed rate@35 kg ha ${ }^{-1}$, where number of matured panicles $\mathrm{m}^{-2}$ was 339 as pooled value. Similar trend was noticed during the kharif 2011 and kharif 2012 (Table 1). The result is in agreement with the findings of Mankotia et al., 2005 and they reported that optimization of seed rate is most important factor for the overall improvement of productivity of rainfed upland rice. On the other hand, among the row spacing treatments, the treatment $\mathrm{R}_{1}$ i.e. $20 \mathrm{~cm}$ row spacing recorded significantly more number of matured panicles $\mathrm{m}^{-2}$ (420) in pooled value (Table 1). This might due to an optimum plant population, was obtained in respective plots with special reference to row spacing $(20 \mathrm{~cm})$. The treatment combination of $\mathrm{S}_{2}$ (seed rate@ $\left.30 \mathrm{~kg} \mathrm{ha}^{-1}\right)$ and $\mathrm{R}_{1}(20 \mathrm{~cm}$ row spacing) recorded the highest number of matured panicles $\mathrm{m}^{-2}$ (456) in pooled value (Table 2). This could be attributed with using both the seed rate @ $30 \mathrm{~kg} \mathrm{ha}^{-1}$ and $20 \mathrm{~cm}$ row spacing and as a result of higher uptake and recovery of applied nutrients. It was noticed that more number of matured panicles $\mathrm{m}^{-2}$ was recorded with the treatment $R_{1}$ (20 cm row spacing), which reflected on the achieving maximum grain yield of aerobic rice. The treatment $\mathrm{R}_{3}$ i.e. $30 \mathrm{~cm}$ row spacing recorded significantly less number of matured panicles $\mathrm{m}^{-2}$ (271) in pooled value (Table 1). The result is coincided with the results of Vijayakumar et al. (2004) and Kandil et al. (2010) and they reported that wider spacing or space allows the individuals plants to produce more tillers but it provides the smaller number of hills per unit area which results in low grain yield.

Panicle weight: Regarding panicle weight, it was not significantly influenced by the levels of seed rate in pooled analysis (Table 1). However, panicle weight was not significantly influenced by seed rate indicating this parameter was more or less stable under changing 
Table 1. Number of matured panicles $\mathrm{m}^{-2}$ and panicle weight of aerobic rice (variety: Kshitish) as influenced by seed rate and row spacing in aerobic situation during kharif season.

\begin{tabular}{|c|c|c|c|c|c|c|}
\hline \multirow[t]{2}{*}{ Treatments } & \multicolumn{3}{|c|}{ No. of matured panicles $\mathrm{m}^{-2}$} & \multicolumn{3}{|c|}{ Panicle weight (g) } \\
\hline & Kharif 2011 & Kharif 2012 & Pooled & $\begin{array}{c}\text { Kharif } \\
2011\end{array}$ & Kharif 2012 & Pooled \\
\hline \multicolumn{7}{|c|}{ Levels of seed rate $\left(\mathrm{kg} \mathrm{ha}^{-1}\right)$} \\
\hline $\mathrm{S}_{1}(25)$ & 328 & 334 & 331 & 1.64 & 1.67 & 1.66 \\
\hline $\mathrm{S}_{2}(30)$ & 365 & 369 & 367 & 1.84 & 1.91 & 1.86 \\
\hline $\mathrm{S}_{3}(35)$ & 337 & 341 & 339 & 1.75 & 1.78 & 1.76 \\
\hline $\operatorname{SEm}( \pm)$ & 4.3 & 7.3 & 4.9 & 0.8 & 0.7 & 0.6 \\
\hline $\mathrm{CD}(0.05)$ & 18 & 22 & 19.6 & NS & NS & NS \\
\hline C.V. $(\%)$ & 6 & 5.62 & 4.82 & 14.64 & 13.73 & 11.52 \\
\hline \multicolumn{7}{|c|}{ Levels of row spacing (cm) } \\
\hline $\mathrm{R}_{1}(20)$ & 421 & 419 & 420 & 1.52 & 1.56 & 1.54 \\
\hline $\mathrm{R}_{2}(25)$ & 336 & 338 & 337 & 1.79 & 1.81 & 1.80 \\
\hline $\mathrm{R}_{3}(30)$ & 273 & 272 & 271 & 1.92 & 1.90 & 1.91 \\
\hline $\operatorname{SEm}( \pm)$ & 7.4 & 5.4 & 6.8 & 0.05 & 0.04 & 0.05 \\
\hline $\mathrm{CD}(0.05)$ & 22 & 18 & 21 & 0.16 & 0.13 & 0.15 \\
\hline C.V. $(\%)$ & 6.16 & 6.20 & 5.68 & 8.97 & 8.77 & 8.65 \\
\hline
\end{tabular}

Table 2. Interaction effects between seed rate and row spacing on number of matured panicles $\mathrm{m}^{-2}$ and panicle weight of aerobic rice (variety: Kshitish) in aerobic situation during kharif season.

\begin{tabular}{|c|c|c|c|c|c|c|c|}
\hline \multirow{2}{*}{$\begin{array}{l}\text { Seed } \\
\text { rates }\end{array}$} & \multirow{2}{*}{$\begin{array}{l}\text { Row spac- } \\
\text { ings }\end{array}$} & \multicolumn{3}{|c|}{ No. of matured panicles $\mathrm{m}^{-2}$} & \multicolumn{3}{|c|}{ Panicle wt. (g) } \\
\hline & & Kharif 2011 & Kharif 2012 & Pooled & $\begin{array}{c}\text { Kharif } \\
2011\end{array}$ & Kharif 2012 & Pooled \\
\hline \multirow[t]{3}{*}{$\mathrm{S}_{1}$} & $\mathrm{R}_{1}$ & 399 & 405 & 402 & 1.36 & 1.39 & 1.37 \\
\hline & $\mathrm{R}_{2}$ & 327 & 332 & 329 & 1.66 & 1.70 & 1.65 \\
\hline & $\mathrm{R}_{3}$ & 259 & 264 & 261 & 1.88 & 1.92 & 1.89 \\
\hline \multirow[t]{3}{*}{$\mathrm{S}_{2}$} & $\mathrm{R}_{1}$ & 454 & 458 & 456 & 1.57 & 1.66 & 1.61 \\
\hline & $\mathrm{R}_{2}$ & 347 & 351 & 349 & 1.93 & 2.03 & 1.98 \\
\hline & $\mathrm{R}_{3}$ & 294 & 298 & 296 & 2.02 & 2.05 & 2.02 \\
\hline \multirow[t]{3}{*}{$\mathrm{S}_{3}$} & $\mathrm{R}_{1}$ & 410 & 413 & 411 & 1.63 & 1.66 & 1.63 \\
\hline & $\mathrm{R}_{2}$ & 335 & 338 & 335 & 1.77 & 1.80 & 1.78 \\
\hline & $\mathrm{R}_{3}$ & 265 & 272 & 268 & 1.86 & 1.89 & 1.87 \\
\hline & ame R & NS & NS & NS & NS & NS & NS \\
\hline \multicolumn{2}{|c|}{$\mathrm{R}$ at same $\mathrm{S}$} & NS & NS & NS & NS & NS & NS \\
\hline \multicolumn{2}{|c|}{ Expt. Mean } & 343 & 343 & 342 & 1.74 & 1.76 & 1.75 \\
\hline
\end{tabular}

Table 3. Grain yield $\left(\mathrm{t} \mathrm{ha}^{-1}\right)$ of aerobic rice (variety: Kshitish) as influenced by seed rate and row spacing in aerobic situation during Kharif season.

\begin{tabular}{lccc}
\hline \multicolumn{1}{c}{ Treatments } & Grain yield $\left(\mathbf{t ~ h a}^{\mathbf{- 1}}\right)$ & Pooled \\
\cline { 2 - 4 } & Kharif 2011 & Kharif 2012 & 3.05 \\
\hline Levels of seed rate $\left(\mathbf{k g ~ h a}^{-\mathbf{1}}\right)$ & & 3.12 & 3.42 \\
\hline $\mathrm{S}_{1}(25)$ & 3.01 & 3.49 & 3.08 \\
$\mathrm{~S}_{2}(30)$ & 3.40 & 3.13 & 0.07 \\
$\mathrm{~S}_{3}(35)$ & 3.06 & 0.06 & 0.29 \\
SEm $( \pm)$ & 0.08 & 0.26 & 10.24 \\
CD $(0.05)$ & 0.31 & 10.73 & 3.46 \\
C.V. $(\%)$ & 11.10 & & 3.36 \\
\hline Levels of row spacing (cm) & & 3.45 & 2.66 \\
\hline $\mathrm{R}_{1}(20)$ & 3.47 & 3.40 & 0.07 \\
$\mathrm{R}_{2}(25)$ & 3.35 & 2.70 & 0.31 \\
$\mathrm{R}_{3}(30)$ & 2.65 & 0.06 & 9.23 \\
SEm $( \pm)$ & 0.08 & 0.30 & 10.93 \\
CD $(0.05)$ & 0.34 & & \\
C.V. $(\%)$ & 10.34 & & \\
\end{tabular}

environment. But, the value of panicle weight was statistically significant by the different row spacing. The highest panicle weight $(1.91 \mathrm{~g})$ was recorded with treatment $R_{3}$ (30 cm row spacing) and lowest value (1.54g) was obtained with $20 \mathrm{~cm}$ row spacing in pooled analysis (Table 1). This might be due to closer spacing, which hampers intercultural operations and increases competition among the rice plants for nutri- 
Table 4. Interaction effects between seed rate and row spacing on grain yield ( $\mathrm{t} \mathrm{ha}^{-1}$ ) of aerobic rice (variety: Kshitish) in aerobic situation during Kharif.

\begin{tabular}{|c|c|c|c|c|c|}
\hline \multicolumn{2}{|c|}{$\begin{array}{l}\text { Levels of seed rate } \\
\left(\mathrm{kg} \mathrm{ha}^{-1}\right)\end{array}$} & $\begin{array}{l}\text { Levels of row spacing } \\
\text { (cm) }\end{array}$ & Kharif 2011 & \multicolumn{2}{|c|}{ Grain yield $\left(\mathrm{t} \mathrm{ha}^{-1}\right)$} \\
\hline & & $\mathrm{R}_{1}(20)$ & 3.31 & 3.41 & 3.36 \\
\hline \multirow[t]{3}{*}{$\mathrm{S}_{1}(25)$} & & $\mathrm{R}_{2}(25)$ & 3.15 & 3.30 & 3.21 \\
\hline & & $\mathrm{R}_{3}(30)$ & 2.56 & 2.66 & 2.60 \\
\hline & & $\mathrm{R}_{1}(20)$ & 3.96 & 4.06 & 4.01 \\
\hline \multirow[t]{3}{*}{$\mathrm{S}_{2}(30)$} & & $\mathrm{R}_{2}(25)$ & 3.52 & 3.61 & 3.54 \\
\hline & & $\mathrm{R}_{3}(30)$ & 2.72 & 2.79 & 2.73 \\
\hline & & $\mathrm{R}_{1}(20)$ & 3.13 & 3.23 & 3.16 \\
\hline \multirow[t]{2}{*}{$\mathrm{S}_{3}(35)$} & & $\mathrm{R}_{2}(25)$ & 3.38 & 3.45 & 3.41 \\
\hline & & $\mathrm{R}_{3}(30)$ & 2.67 & 2.72 & 2.68 \\
\hline \multirow{2}{*}{\multicolumn{2}{|c|}{$\begin{array}{l}\mathrm{S} \text { at same } \mathrm{R} \\
\mathrm{R} \text { at same } \mathrm{S}\end{array}$}} & & NS & NS & NS \\
\hline & & & NS & NS & NS \\
\hline \multicolumn{3}{|c|}{ Expt. Mean } & 3.15 & 3.18 & 3.16 \\
\hline
\end{tabular}

NS: Not Significant.

ents, air, light and water; which results in weaker plants, reduced panicle weight and mutual shading thus favours more straw yield than grain yield. As we know that population pressure had a major effect on morphological and physiological characters as well as yield. Leaf area plant ${ }^{-1}$ was higher in wider spacing and lower in closer spacing. This might be due to limitation of light, nutrients and water in densely populated plants and vice-versa. As a results, higher value of panicle weight as well as leaf area were produced in lower population levels (wider spacing) which have the capacity to capture more sunlight because of less mutual shading effect among the leaves and less competition for nutrients in wider spacing. The result is coincided with the results of Faisul-ur-Rasool et al. (2013) and he reported the wider plant spacing significantly recorded higher panicle weight as compared to closer spacing. But highest number of effective tillers $\mathrm{m}^{-2}$ was recorded from $20 \mathrm{~cm}$ row spacing, which reflected on grain yield of aerobic rice. The result is in agreement with the findings of Kandil et al. (2010) and he reported that wider row spacing provides the higher value of panicle weight, but closer row spacing provides the higher number of effective tillers per unit area which results in higher grain yield.

Grain yield: The treatment $\mathrm{S}_{2}$ i.e. seed rate@ $30 \mathrm{~kg}$ $\mathrm{ha}^{-1}$ recorded highest gain yield $\left(3.42 \mathrm{tha}^{-1}\right)$ of rice [cv. Kshitish (IET 4094)] in aerobic situation in pooled analysis and similar trend was observed during both the years, though the yield increased with increase in seed rate upto $30 \mathrm{~kg} \mathrm{ha}^{-1}$ (Table 3 ). Then yield decreased with increase in seed rate at $35 \mathrm{~kg} \mathrm{ha}^{-1}$ and this might be due to higher plant population per unit area. Decreased in grain yield may be due to increase in competition among the rice plants for water, nutrients, air and light etc., which resulted in weaker plants and ultimately produced lower grain yield, when used the higher seed rate. The results are in agreement with the findings of Hari et al. (1997), Rajendra and Veeraputhiran (1999) and they reported that low seed rate resulted high seeding quality and leaf area per plant.
Higher seeding rate $\left(35 \mathrm{~kg} \mathrm{ha}^{-1}\right)$ is one approach that helps in increasing crop competitiveness against weeds. High seeding rate facilitate quick canopy closure, which helps suppress weeds more effectively. A despite improvement in weed management, higher seeding rate $\left(35 \mathrm{~kg} \mathrm{ha}^{-1}\right)$ may exacerbate problems like lodging (Bond et al., 2005), insect and diseases infestation (Tan et al., 2000) and rat damaged that harm the crop yield. Another reason is that high seed rate $(35 \mathrm{~kg}$ $\mathrm{ha}^{-1}$ ) may bring about problem of mutual shading and intra-specific competition for below-ground resources. At low seeding rate $\left(25 \mathrm{~kg} \mathrm{ha}^{-1}\right)$ rice crop plants take more time to close their canopy which encourages the weed growth. On the other hand, treatment $\mathrm{S}_{2}$ i.e. seed rate@30 $30 \mathrm{~kg} \mathrm{~h}^{-1}$ (as medium seed rate) helps in suppression of weed population as well as produced maximum of number of matured panicles $\mathrm{m}^{-2}$ and highest value of panicle weight and ultimately produced highest grain yield $\left(3.42 \mathrm{t} \mathrm{ha}^{-1}\right)$ of aerobic rice. The results are in agreement with the findings of El-Kallawy (2002) who studied the effect of different seeding rates and found that low seed rate has significantly raised the seedling vigour where it gave the highest values of leaf area per plant and leaf number per stem. There was a remarkable difference in respect of yield and yield contributing characters due to spacing. Among the row spacing's treatments, treatment $\mathrm{R}_{1}$ i.e. $20 \mathrm{~cm}$ row spacing recorded significantly higher grain yield (3.47, 3.45 and $3.46 \mathrm{t} \mathrm{ha}^{-1}$ during kharif 2011, kharif 2012 and pooled value, respectively) (Table 3). This might be due to better root growth and proliferation and also opportunity to extract water and nutrients both from larger soil profile area, which in turn must have improved synthesis and translocation of metabolites to various reproductive structures of rice plant and better distribution of it into grain would always results in higher grain yield. Another reason is that the maximum number of matured panicles $\mathrm{m}^{-2}$ was obtained from $20 \mathrm{~cm}$ row spacing. Higher grain yield was obtained from $20 \mathrm{~cm}$ apart row spacing due to increased number of effective tillers $\mathrm{m}^{-2}$. Grain yield of aerobic 
rice [cv. Kshitish (IET 4094)] at 20 and $25 \mathrm{~cm}$ row spacing's were statistically at par. The result is partially coincided with the results of Jalil (2008) who stated that the rice crop (cv. BRRI dhan 29) with $25 \mathrm{~cm}$ row spacing produced highest grain yield under aerobic system of cultivation. The results from the Table 4 revealed that rice crop sown in lines $20 \mathrm{~cm}$ apart with seed rate@30 kg ha ${ }^{-1}$ resulted in a saving of seed without any reduction in the grain yield compared to sown in lines $25 \mathrm{~cm}$ apart with seed rate @ $35 \mathrm{~kg} \mathrm{ha}^{-1}$. The results are in agreement with the findings reported by Singh et al., 2004 and he advocated that upland rice crop should be sown in lines at $20 \mathrm{~cm}$ apart in different parts of the India. The lowest grain yield (2.66 t ha ${ }^{-1}$ as pooled value) was obtained with the treatment $R_{3}$ (30 $\mathrm{cm}$ row spacing) in aerobic situation during both the years and in pooled analysis as wider plant spacing (30 $\mathrm{cm}$ row spacing) reduces grain yield per unit area. IRRI (1997) reported that improper spacing reduced yield up to $20-30 \%$. On the other hand, optimum plant spacing ensures the plant to grow properly with their aerial and under-ground parts by utilizing more solar radiation and nutrients. The result is coincided with the results of Mohaddesi et al. (2011) and they reported that the optimum spacing ensures the plant to grow in their both aerial and underground parts through efficient utilization of solar radiation and nutrients. Plant spacing directly affect the normal physiological activities through intra-specific competition (Oad et al., 2001). When the planting density exceed the optimum level, competition among plants for light above ground or for nutrients below ground becomes severe and consequently the growth slows down and the grain yield decreases. The treatment combination of $\mathrm{S}_{2}$ (seed rate (a) $\left.30 \mathrm{~kg} \mathrm{ha}^{-1}\right)$ and $\mathrm{R}_{1}(20 \mathrm{~cm}$ row spacing) recorded the highest grain yield $\left(4.01 \mathrm{t} \mathrm{ha}^{-1}\right)$ of aerobic rice (Table $4)$. The results revealed that number of matured panicles $\mathrm{m}^{-2}$ and grain yield increased with row spacing of $20 \mathrm{~cm}$ apart and likely the highest grain yield was observed in row spacing of $20 \mathrm{~cm}$ apart due to superiority in yield contributing characters (Table 1). The results are in agreement with the findings of Das et al. (1988) and he reported that closer spacing has been found to compensate the loss in yield due to greater number of plants and tiller population per unit area of land. The result is coincided with the results of Faisul-ur-Rasool et al. (2013) and reported that plant spacing caused the variation in yield parameter. The wider plant spacing significantly recorded higher panicle weight as compared to closer spacing. The wider spacing adopted more appears to be an advantageous for better development of panicles. However, the case was just reversed for number of effective tillers $\mathrm{m}^{-2}$, being maximum under closer spacing and lowest under wider spacing. The possible reason may be the more number of plants with closer spacing than with wider spacing. The result is coincided with the results of Ather Nadeem et al.
(2004) and he reported that increase in grain yield can be ensured by maintaining appropriate plant population through different planting patterns and the suitable plant density is an effective factor on yield increases. The results are in agreement with the findings of Omina EL-Shayieb (2003) and he showed that narrow spacing gave the highest yield and yield components of rice cultivars compared with wider spacing.

\section{Conclusion}

The results of this experiment established that seed rate (a) $30 \mathrm{~kg} \mathrm{ha}^{-1}$ and $20 \mathrm{~cm}$ row spacing were promising for realizing best grain yield of aerobic rice in aerobic situation. The treatment combination of $\mathrm{S}_{2}$ (seed rate (a) $\left.30 \mathrm{~kg} \mathrm{ha}^{-1}\right)$ and $\mathrm{R}_{1}(20 \mathrm{~cm}$ row spacing) recorded the highest grain yield $\left(4.01 \mathrm{t} \mathrm{ha}^{-1}\right)$ of aerobic rice. From the present investigation, it may be concluded that the seed rate@30 kg ha ${ }^{-1}$ and 20 cm row spacing are suitable for obtaining highest grain yield of aerobic rice. In recent years, uneven distribution, erratic pattern and irregular rains due to climate change (global warming) has limited rice cultivation. Aerobic rice cultivation is a sustainable rice production methodology for immediate future to address water scarcity and environmental safety arising due to global warming. Aerobic rice is the rice for the future.

\section{ACKNOWLEDGEMENTS}

The authors would like to thanks Dr. P. K. Maity, Chief Agronomist, FCRS, Burdwan; Mr. M. Dhara, Agronomist, RRS, Chinsurah; Mr. S. R. Patra, Additional Joint Director of Agriculture (Research); Dr. P. Bhattacharyay, Director of Agriculture, Writers' Building, Kolkata -1 and Prof. B. K. Mandal, retired Professor and former Head, Prof. A. M. Puste, Prof. S. B. Goswami, Prof. K. Brahmachari, Prof. B. C. Patra, Department of Agronomy, Bidhan Chandra Krishi Viswavidyalay, Mohanpur, Nadia, West Bengal, India for their valuable guidance and encouragement during the period of this research programme.

\section{REFERENCES}

Ather, N.M., Ali, R., Sohail, R. and Maqbool, M. (2004). Effect of different pattern on growth, yield and quality of grain legumes. Pak. J. Life Soc. Sci., 2 (2): 132-135

Barker, R., Dawe, D., Tuong, T.P., Bhuiyan, S.I. and Guerra, L.C. (1999). The outlook of water resources in the year 2020: Challenges for research on water management in rice production. Assessment and orientation towards the $21^{\text {st }}$ century, : 96-109

Bond, J.A., Walker, T.W., Bollich, P.K., Koger, C.H. and Gerard, P. (2005). Seeding rates for stale seedbed rice production in the mid-southern United States. Agron. J., 97: $1560-1563$

Bouman, B.A.M. and Tuong, T.P. (2001). Field water management to save water and increase its productivity in irrigated rice. Agricultural Water Management, 49 (1): $11-30$ 
Bouman, B.A.M., Peng, S., Castaneda, A.R. and Visperas, R.M. (2005). Yield and water use of irrigated tropical aerobic rice systems. Agricultural Water Management, 74: $87-105$

Das, K., Biswal, D. and Pradhan, T. (1988). Effect of plant density and age of seedlings on the growth and yield of rice variety, Parijat. Oryza, 25: 191-194

Eitzinger, J., Orlandini, S., Stefanski, R. and Naylor, R.E.L. (2010). Climate Change and agriculture: Introductory editorial. Journal of Agricultural Sciences, Cambridge, 148: 499-500

El-Kallawy, WHM. (2002). Effect of some agronomic practices on growth and yield of rice. M.Sc. Thesis, Agron. Dept. Fac. Agric. Kafr EL-Sheikh, Tanta Univ.,

El-Shayieb, O.M.A. (2003). Agronomic study on rice crop. M.Sc. Thesis. Agronomy Department, Faculty of Agriculture, Mansoura University, Egypt

Faisul, U.R., Habib, R. and Bhat, M.I. (2013). Evaluation of plant spacing and seedling per hill on rice (Oryza sativa L.) productivity under temperate conditions. Pak. J. Agric. Sci., 49: 169-172

Hari, O.M., Katyal, S.K. and Dhiman, S.K. (1997). Growth analysis of hybrid rice as influenced seeding density in nursery and nitrogen levels. Haryana Agric. Uni. J. Res., 27 (2): 127-130

IPPC (Inter-Governmental Panel on Climate Change) (2007). Climate change and its impacts in the near and long term under different scenarios. In Climate Change 2007: Synthesis Report (Eds the Core Writing Team, R. K. Pachauri \& Reisinger), Geneva, Switzerland: IPCC, pp. 43-54

IRRI (International Rice Research Institute). (1997). Rice Production Manual. UPLB, Los Banos, The Philippines: 95

Jalil, M.A. (2008). Effect of spacing and rate of fertilizer application on yield performance of boro rice (cv. BRRI dhan 29) under aerobic system of cultivation. M.S. Thesis, Dept. of Agron., Bangladesh Agril. Univ., pp: 48-49

Jana, K. (2012a). Effect of nitrogen levels and weed management practices on grain yield of aerobic rice cultivation system. Green farming, 3 (6): 687-689

Jana, K. (2012b). Aerobic rice system towards tackling climate change. SATSA MUKHAPATRA - Annual technical issue, 16: 81-88

Jana, K. (2013). Evaluation of aerobic rice system during boro season under red and laterite zone of West Bengal. Crop Research - An International Journal, 45 (No. 1, 2 \& 3): 20-23
Kandil, A.A., El-Kalla, S.E., Badwani, A.T. and El-Shayb, O.M. (2010). Effect of hill spacing, nitrogen levels and harvest date on rice productivity and grain quality. Crop Environment, 1: 22-26

Kathiresan, G. and Manoharan, M.L. (2002). Effect of seed rate and method of weed control on weed growth and yield of direct-sown rice (Oryza sativa). Indian Journal of Agronomy, 47: 212-215

Mankotia, B.S. and Shekar, J. (2005). Studies on Integrated nutrient supply and seed rate for direct seeded rianfed upland rice in mid hills of Himachal Pradesh. Journal of Rice Research, 2 (1): 23-26

Mohaddesi, A.A.A., Bakhshipour, S. and Aminpanah, H. (2011). Effrect of different levels of nitrogen and plant spacing on yield yield components and physiological indices in high yield rice. Amer-Eur: J. Agric. Environ., 10: 893-900

Oad, F.C., Solangi, B.K. Samo, M.A. Lakho, A.A., Hassan, Z.U. and Oad, N.L. (2001). Growth, yield and relationship of rapeseed under different row spacing. Int. $J$ Agric. Biol., 3: 475-476

Rajendra, K. and Veeraputhiran, R. (1999). Effect of seed rates and nitrogen levels on hybrid rice (Oryza sativa). Madras Agric. J., 86 (7-9): 459-460

Singh, V.K., Gupta, D.K. and Sinha, A.K. (2004). Integrated crop management for upland rainfed rice under northern hill region of chattisgarh. In: Proc. International symposium on Rainfed Rice Ecosystem: Perspective and potential, 11-13 October, 2004 held at Indira Gandhi Agricultural University, Raipur, Chattisgarh, India: 7879

Tan, P.S., Khuong, T.Q. and Hoai, N.T. (2000). Low cost technologies for rice production in the ekong delta. In: Proceedings of the Paper presented at National Workshop on September 21- 23. Ho Chi Minh City, Vietnam, pp. 14

Vijayakumar, M., Singh, S.P.S., Prabhakaran, N.K. and Thiyagarajan, T.M. (2004). Effect of SRI practices on the yield attributes, yield and water productivity of rice. Acta Agron., 52: 399-408

Wang, H., Bouman, B.A.M., Dule, Z., Wang, C. and Moya, P.F. (2002). Aerobic rice in northern China: opportunities and challenges. Water-wise rice production. Proceedings of the International Workshop on water-wise Rice Production, IRRI, April. 8-11, 2002, Los Banos, Philippines : $143-154$ 